Article

\title{
Dehydrogenation of Cycloalkanes over N-Doped Carbon-Supported Catalysts: The Effects of Active Component and Molecular Structure of the Substrate
}

\author{
Jian Wang ${ }^{\dagger}$, He Liu ${ }^{*}{ }^{\dagger}$, Shiguang Fan, Shuai Wang, Guanjun Xu, Aijun Guo and Zongxian Wang * \\ State Key Laboratory of Heavy Oil Processing, College of Chemical Engineering, \\ China University of Petroleum (East China), Qingdao 266580, China; j.wang@s.upc.edu.cn (J.W.); \\ sgf@s.upc.edu.cn (S.F.); z20030074@s.upc.edu.cn (S.W.); z19030053@s.upc.edu.cn (G.X.); ajguo@upc.edu.cn (A.G.) \\ * Correspondence: liuhe@upc.edu.cn (H.L.); heavyoil@upc.edu.cn (Z.W.); \\ Tel.: +86-0532-86980607 (H.L.); Fax: +86-0532-86981787 (H.L.) \\ + These authors contributed equally to this work.
}

check for

updates

Citation: Wang, J.; Liu, H.; Fan, S.; Wang, S.; Xu, G.; Guo, A.; Wang, Z. Dehydrogenation of Cycloalkanes over N-Doped Carbon-Supported Catalysts: The Effects of Active

Component and Molecular Structure of the Substrate. Nanomaterials 2021, 11, 2846. https://doi.org/ $10.3390 /$ nano11112846

Academic Editor:

Inmaculada Rodríguez-Ramos

Received: 13 October 2021

Accepted: 22 October 2021

Published: 26 October 2021

Publisher's Note: MDPI stays neutral with regard to jurisdictional claims in published maps and institutional affiliations.

Copyright: (C) 2021 by the authors. Licensee MDPI, Basel, Switzerland. This article is an open access article distributed under the terms and conditions of the Creative Commons Attribution (CC BY) license (https:// creativecommons.org/licenses/by/ $4.0 /)$.
Abstract: Efficient dehydrogenation of cycloalkanes under mild conditions is the key to large-scale application of cycloalkanes as a hydrogen storage medium. In this paper, a series of active metals loaded on nitrogen-doped carbon $(\mathrm{M} / \mathrm{CN}, \mathrm{M}=\mathrm{Pt}, \mathrm{Pd}, \mathrm{Ir}, \mathrm{Rh}, \mathrm{Au}, \mathrm{Ru}, \mathrm{Ag}, \mathrm{Ni}, \mathrm{Cu}$ ) were prepared to learn the role of active metals in cycloalkane dehydrogenation with cyclohexane as the model reactant. Only $\mathrm{Pt} / \mathrm{CN}, \mathrm{Pd} / \mathrm{CN}, \mathrm{Rh} / \mathrm{CN}$ and $\mathrm{Ir} / \mathrm{CN}$ can catalyze the dehydrogenation of cyclohexane under the set conditions. Among them, $\mathrm{Pt} / \mathrm{CN}$ exhibited the best catalytic activity with the TOF value of $269.32 \mathrm{~h}^{-1}$ at $180{ }^{\circ} \mathrm{C}$, followed by $\mathrm{Pd} / \mathrm{CN}, \mathrm{Rh} / \mathrm{CN}$ and $\mathrm{Ir} / \mathrm{CN}$ successively. More importantly, the difference of catalytic activity between these active metals diminishes with the increase in temperature. This implies that there is a thermodynamic effect of cyclohexane dehydrogenation with the synthetic catalysts, which was evidenced by the study on the activation energy. In addition, the effects of molecular structure on cycloalkane dehydrogenation catalyzed by $\mathrm{Pt} / \mathrm{CN}$ were studied. The results reveal that cycloalkane dehydrogenation activity and hydrogen production rate can be enhanced by optimizing the type, quantity and position of alkyl substituents on cyclohexane.

Keywords: hydrogen; Pt; cycloalkanes; dehydrogenation; molecular structure

\section{Introduction}

Hydrogen is considered to be a promising alternative for widely used fossil fuels, because it has a high calorific value and is pollution-free [1,2]. However, hydrogen is flammable and explosive, which raises some safety concerns, thus hindering the largescale commercial applications [3,4]. Liquid organic hydrogen carriers (LOHCs), storing hydrogen in their molecular structures, have been developed to overcome problems in safe storage and transportation of hydrogen [5-10]. As a kind of common LOHC, cycloalkanes hold high hydrogen storage density (5-8 wt\%) and exhibit excellent chemical and thermal stability [11]. Furthermore, cycloalkanes are commonly used industrial chemicals which have realized long-distance transportation and large-scale storage in the chemical industry. However, the release of hydrogen in cycloalkanes is difficult because of the high thermodynamic limitation in C-H bond cleavage [5,12-14]. Extensive studies found that cycloalkane dehydrogenation with heterogeneous catalysts should be carried out in gas-phase at high temperature (above $300{ }^{\circ} \mathrm{C}$ ) to obtain a high hydrogen production rate and cycloalkane conversion [11]. However, the high temperature in cycloalkane dehydrogenation might lead to catalyst deactivation and impure hydrogen $[15,16]$. Furthermore, the harsh reaction condition of cycloalkane dehydrogenation hinders the applications carried out under mild conditions, such as fuel cells [17].

Recently, "wet-dry multiphase conditions", the dehydrogenation technology under reactive distillation conditions, has been developed to overcome the thermodynamic 
limitation in C-H bond cleavage, which can obtain high cycloalkane conversion and high hydrogen purity at low temperatures around $200{ }^{\circ} \mathrm{C}[18,19]$. However, this technology is also accompanied by a low hydrogen production rate under mild conditions, which remains a key challenge in large-scale applications. One strategy is to develop a highly efficient catalyst for cycloalkane dehydrogenation under mild conditions. A series of Pt-based catalysts with excellent dehydrogenation performance under mild conditions (around $200{ }^{\circ} \mathrm{C}$ ) have been intensively studied for cycloalkane dehydrogenation [18-24]. Li et al. investigated decalin dehydrogenation over $5 \mathrm{wt} \% \mathrm{Pt} / \mathrm{p}$-CNFs catalyst under wet-dry multiphase conditions [19]. The result revealed that the $\mathrm{Pt} / \mathrm{p}-\mathrm{CNFs}$ catalyst exhibited the excellent dehydrogenation performance with the conversion of $46.32 \%$ and TOF of $732.4 \mathrm{~mol} \mathrm{H}_{2} / \mathrm{mol}$ metal at $240{ }^{\circ} \mathrm{C}$ after $2 \mathrm{~h}$. Hodoshima et al. studied the enhancement of dehydrogenation performance of Pt-based catalyst by the addition of Ir and $\mathrm{W}$ under wet-dry multiphase conditions [23]. The decalin conversions over Pt/C, PtIr/C and $\mathrm{PtW} / \mathrm{C}$ were $26.5 \%, 32 \%$ and $37.3 \%$ at $210{ }^{\circ} \mathrm{C}$ after $2.5 \mathrm{~h}$, respectively. In our previous work, $\mathrm{Pt} / \mathrm{CN}$ catalyst was employed in cyclohexane dehydrogenation with the cyclohexane conversion of $96.03 \%$ at $210{ }^{\circ} \mathrm{C}$ after $1.5 \mathrm{~h}$ [24]. In addition, many other metals ( $\mathrm{Pd}, \mathrm{Ag}$, $\mathrm{Ni}, \mathrm{Cu}$, etc.) exhibited good catalytic performance in cycloalkanes dehydrogenation at elevated temperatures around $300^{\circ} \mathrm{C}[16,25-28]$. However, limited studies focused on the catalytic cycloalkane dehydrogenation under mild reaction conditions.

In addition to the catalysts, the molecular structures of cycloalkanes affect the dehydrogenation activity as well $[5,22,29]$. Kariya et al. revealed that dehydrogenation of methylcyclohexane over $\mathrm{Pt} / \mathrm{AC}$ cloth at $298^{\circ} \mathrm{C}$ exhibited better dehydrogenation activity comparable with that of cyclohexane at $330^{\circ} \mathrm{C}$ [22]. Crabtree et al. studied the effect of amino groups on the dehydrogenation performance of cycloalkanes by theoretical calculation. The results showed that the temperature of hydrogen released by cycloalkanes gradually decreased with the increase in amino quantity [30]. Moreover, the enhancement of dehydrogenation activity by ethyl group in dodecahydro-N-ethylcarbazole dehydrogenation has been reported [31]. However, there is still a lack of systematic research on the effect of molecular structure on the dehydrogenation performance of cycloalkanes.

In this paper, we explored the role of metal ( $\mathrm{Pt}, \mathrm{Pd}, \mathrm{Rh}$ and $\mathrm{Ir}$ ) nanoparticles supported on nitrogen-doped carbon $(\mathrm{CN})$ for cycloalkane dehydrogenation under wet-dry multiphase conditions with cyclohexane as the model reactant. Furthermore, the effects of type, quantity and position of alky substituents on cyclohexane for cycloalkanes dehydrogenation were investigated with $\mathrm{Pt} / \mathrm{CN}$ as the model catalyst.

\section{Experimental Section}

2.1. Catalyst Preparation

\subsubsection{Synthesis of the Nitrogen-Doped Carbon Support (CN)}

The nitrogen-doped carbon support (CN) was synthesized according to our previous report [24]. Briefly, dicyandiamide (1 g), glucose $(1 \mathrm{~g})$ and colloidal silica template $(3 \mathrm{~mL})$ were added in $40 \mathrm{~mL}$ of ultrapure water under stirring. Then, the mixture was heated at $120{ }^{\circ} \mathrm{C}$ until dried. The obtained yellow powder was then calcined under nitrogen atmosphere at $1000{ }^{\circ} \mathrm{C}$ for $3 \mathrm{~h}$. After cooling to room temperature, the black solid was washed with $2 \mathrm{M}$ of $\mathrm{NaOH}$ solution at $120^{\circ} \mathrm{C}$ for $24 \mathrm{~h}$. The precipitate was filtered via $220 \mathrm{~nm}$ organic diameter and washed with ultrapure water. $\mathrm{CN}$ support was collected after vacuum drying.

\subsubsection{Preparation of $\mathrm{M} / \mathrm{CN}$ Catalysts}

$\mathrm{M} / \mathrm{CN}$ catalysts were prepared as follows [32]: CN support (400 $\mathrm{mg}$ ) and a certain amount of metal salt (the metal quality was $5 \mathrm{wt} \%$ of $\mathrm{CN}$ ) were added in $40 \mathrm{~mL}$ of ultrapure water successively. Subsequently, the above solution was sonicated for $30 \mathrm{~min}$ and then stirred at room temperature for $24 \mathrm{~h}$. Finally, the mixture was reduced by $50 \mathrm{mg}$ of sodium borohydride at $80^{\circ} \mathrm{C}$ for $40 \mathrm{~min}$. The products were washed with ultrapure water and collected after vacuum drying. The catalysts prepared from $\mathrm{H}_{2} \mathrm{PtCl}_{6} \cdot 6 \mathrm{H}_{2} \mathrm{O}, \mathrm{Na}_{2} \mathrm{PdCl}_{4}$, 
$\mathrm{IrCl}_{3} \cdot \times \mathrm{H}_{2} \mathrm{O}, \mathrm{Na}_{3} \mathrm{RhCl}_{6}, \mathrm{HAuCl}_{4} \cdot 4 \mathrm{H}_{2} \mathrm{O}, \mathrm{RuCl}_{3}, \mathrm{AgNO}_{3}, \mathrm{NiCl}_{2} \cdot 6 \mathrm{H}_{2} \mathrm{O}$ and $\mathrm{Cu}\left(\mathrm{NO}_{3}\right)_{2} \cdot 3 \mathrm{H}_{2} \mathrm{O}$ are labeled as $\mathrm{Pt} / \mathrm{CN}, \mathrm{Pd} / \mathrm{CN}, \mathrm{Ir} / \mathrm{CN}, \mathrm{Rh} / \mathrm{CN}, \mathrm{Au} / \mathrm{CN}, \mathrm{Ru} / \mathrm{CN}, \mathrm{Ag} / \mathrm{CN}, \mathrm{Ni} / \mathrm{CN}$ and $\mathrm{Cu} / \mathrm{CN}$, respectively.

\subsection{Characterization of Catalysts}

The X-ray diffraction (XRD) patterns and X-ray photoelectron spectroscopy (XPS) spectra were acquired on the $X^{\prime}$ Pert Pro MPD X-ray diffractometer (Malvern Panalytical Ltd., Worcestershire, UK) and Thermo Fisher X-ray photoelectron spectrometer (Thermo Fisher Scientific, Waltham, MA, USA), respectively. The $\mathrm{N}_{2}$ adsorption/desorption isotherms of $\mathrm{CN}$ and the as-prepared catalysts were analyzed using a Micromeritics ASAP 2020 instrument (Micromeritics, Norcross, GA, USA) and calculated by BET method. The transmission electron microscope (TEM) images and high-resolution transmission electron microscope (HRTEM) images of the as-prepared catalysts were collected from a JEM-2100UHR transmission electron microscope (Jeol Ltd., Tokyo, Japan) at the accelerating voltage of $100 \mathrm{kV}$ and $200 \mathrm{kV}$, respectively.

\subsection{Catalytic Testing}

The cycloalkanes dehydrogenation was performed in nitrogen atmosphere under the "wet-dry" multiphase conditions. Typically, $120 \mathrm{mg}$ of M/CN catalyst and $340 \mathrm{mg}$ of cycloalkanes were added to the reaction tube, which were placed in an oil bath to reach the required temperature. The volume of gas products was recorded online through the gas flowmeter. The compositions of gas and liquid products were determined by gas chromatography.

\section{Results and Discussion}

\subsection{Effect of Metals}

Various nitrogen-doped carbon supported metal catalysts (M/CN, M = Pt, Pd, Ir, Rh, $\mathrm{Au}, \mathrm{Ru}, \mathrm{Ag}, \mathrm{Ni}, \mathrm{Cu}$ ) were prepared by fixing the mass ratio of the metal to the $\mathrm{CN}$ support as $5 \mathrm{wt} \%$. The catalytic activity of M/CN catalyst in cycloalkane dehydrogenation have been tested with cyclohexane as the model compound. The cyclohexane dehydrogenation was performed at $180^{\circ} \mathrm{C}$ (catalyst surface temperature) under the "wet-dry" multiphase conditions. Only $\mathrm{Pt} / \mathrm{CN}, \mathrm{Pd} / \mathrm{CN}, \mathrm{Rh} / \mathrm{CN}$ and $\mathrm{Ir} / \mathrm{CN}$ exhibited catalytic activity for cyclohexane dehydrogenation under the set conditions, and other synthetic catalysts were inactive (as shown in Table S1). Therefore, the four catalysts ( $\mathrm{Pt} / \mathrm{CN}, \mathrm{Pd} / \mathrm{CN}, \mathrm{Rh} / \mathrm{CN}$ and $\mathrm{Ir} / \mathrm{CN}$ ) for cyclohexane dehydrogenation were studied in detail. The active metal contents in $\mathrm{Pt} / \mathrm{CN}, \mathrm{Pd} / \mathrm{CN}, \mathrm{Rh} / \mathrm{CN}$ and $\mathrm{Ir} / \mathrm{CN}$ catalysts were $3.22 \mathrm{wt} \%, 2.64 \mathrm{wt} \%, 2.69 \mathrm{wt} \%$ and $2.32 \mathrm{wt} \%$, respectively, which were determined by inductively coupled plasma atomic emission spectroscopy (ICP-AES) and listed in Table 1. In addition, the element analysis of C, N, O in the CN support are shown in Table S2.

Table 1. The physicochemical properties of the $\mathrm{CN}$ support and synthetic catalysts.

\begin{tabular}{|c|c|c|c|c|c|c|}
\hline Sample & Metal $(w t \%)^{1}$ & $\begin{array}{c}\text { Mean Size } \\
(\mathrm{nm})^{2}\end{array}$ & Dispersion $(\%)^{3}$ & $\mathrm{~S}_{\mathrm{BET}}\left(\mathrm{m}^{2} / \mathrm{g}\right)^{4}$ & $\mathrm{~V}_{\text {total }}\left(\mathrm{cm}^{3} / \mathrm{g}\right)^{4}$ & $\mathrm{~d}_{\mathrm{BJH}}(\mathrm{nm})^{4}$ \\
\hline $\mathrm{CN}$ & - & - & - & 965.17 & 2.53 & 10.70 \\
\hline $\mathrm{Pt} / \mathrm{CN}$ & 3.22 & $2.07 \pm 0.13$ & 54.30 & 917.55 & 2.35 & 10.55 \\
\hline $\mathrm{Pd} / \mathrm{CN}$ & 2.64 & $2.46 \pm 0.27$ & 45.55 & 929.55 & 2.37 & 10.57 \\
\hline $\mathrm{Rh} / \mathrm{CN}$ & 2.32 & $2.29 \pm 0.34$ & 48.21 & 943.88 & 2.40 & 10.53 \\
\hline $\mathrm{Ir} / \mathrm{CN}$ & 2.69 & $2.50 \pm 0.32$ & 43.97 & 935.79 & 2.40 & 10.58 \\
\hline
\end{tabular}

${ }^{1}$ analyzed by ICP-AES. ${ }^{2}$ counted from TEM images. ${ }^{3}$ calculated from the Equation (2). ${ }^{4}$ collected from $\mathrm{N}_{2}$ adsorption/desorption isotherm.

The morphologies of the $\mathrm{Pt} / \mathrm{CN}, \mathrm{Pd} / \mathrm{CN}, \mathrm{Rh} / \mathrm{CN}$ and $\mathrm{Ir} / \mathrm{CN}$ catalysts were investigated by TEM and HRTEM and presented in Figure 1. The TEM images of four catalysts display that ultrasmall metal nanoparticles disperse well on the CN support. Figure S1 
depicts the size distributions of metal nanoparticles on $\mathrm{Pt} / \mathrm{CN}, \mathrm{Pd} / \mathrm{CN}, \mathrm{Rh} / \mathrm{CN}$ and $\mathrm{Ir} / \mathrm{CN}$ catalysts. The average particle sizes of $\mathrm{Pt}, \mathrm{Pd}, \mathrm{Rh}$ and $\mathrm{Ir}$ were calculated to be $2.07 \pm 0.13$, $2.46 \pm 0.27,2.5 \pm 0.32$ and $2.29 \pm 0.34 \mathrm{~nm}$, respectively. Obvious lattice fringes were observed in the HRTEM images. The interplanar distance of lattice fringes were calculated to be $0.226,0.224,0.219$ and $0.221 \mathrm{~nm}$, corresponding to (111) plane of Pt, Pd, Rh and Ir, respectively. XRD patterns of $\mathrm{M} / \mathrm{CN}(\mathrm{M}=\mathrm{Pt}, \mathrm{Pd}, \mathrm{Rh}$ and $\mathrm{Ir})$ are presented in Figure 2. Peaks of (111) plane of corresponding metal can be clearly observed in the XRD patterns of M/CN catalysts, which match well with the diffraction peaks of Pt (PDF-04-0802), Pd (PDF-46-1043), Rh (PDF-05-0685) and Ir (PDF-46-1044), respectively.

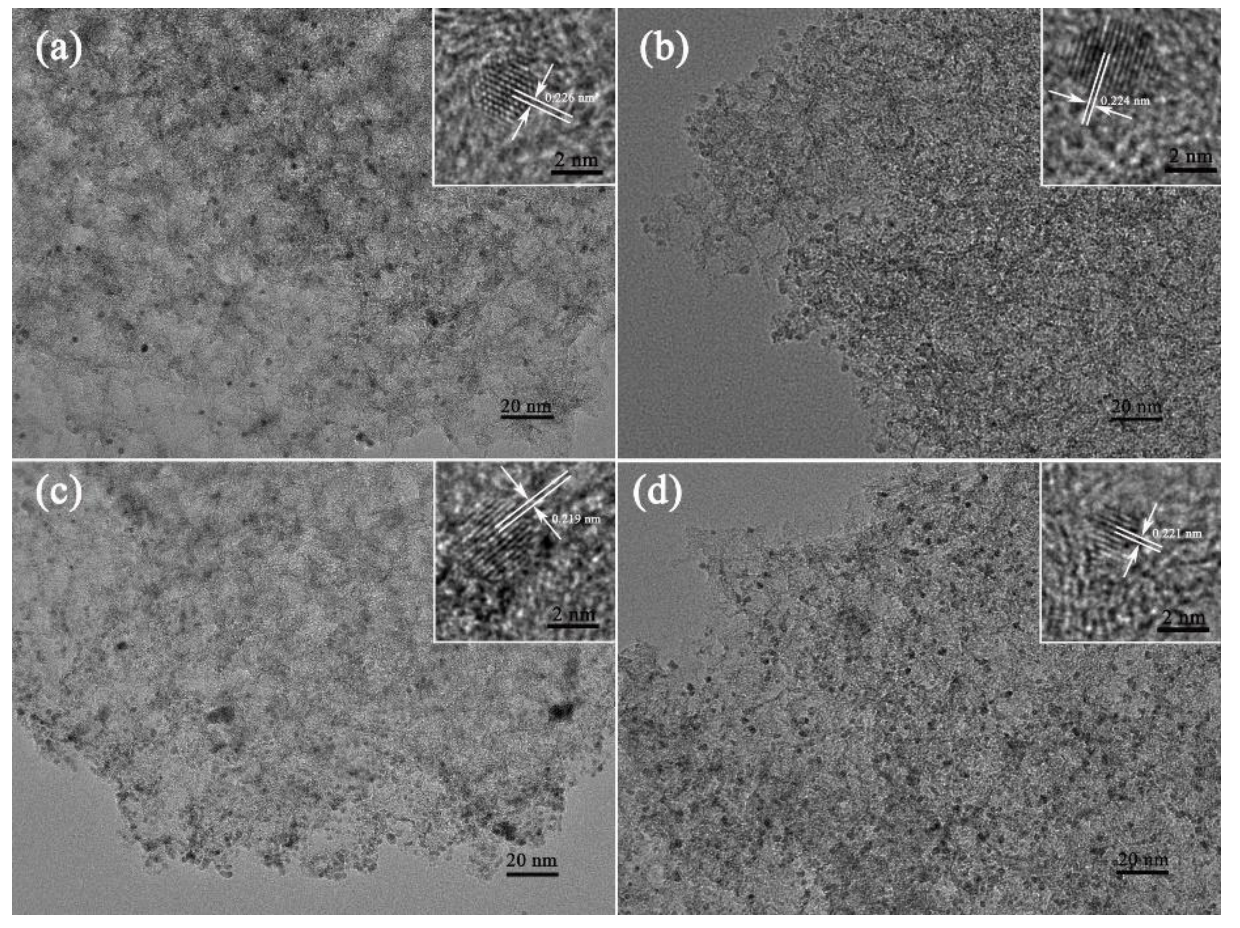

Figure 1. TEM and HRTEM (inset) images of (a) Pt/CN, (b) Pd/CN, (c) Rh/CN and (d) Ir/CN.

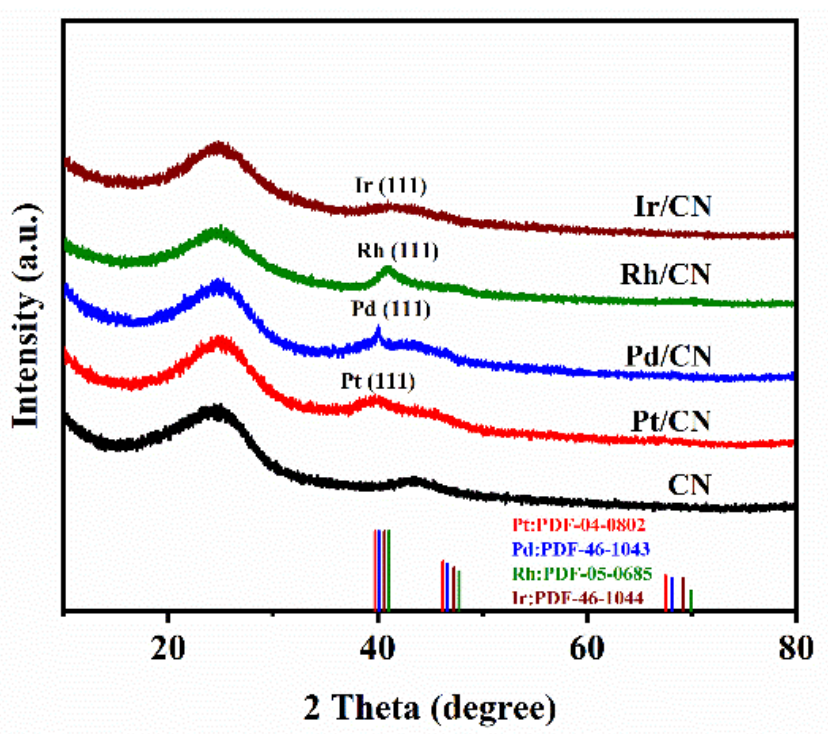

Figure 2. The XRD patterns of the $\mathrm{CN}$ support and $\mathrm{M} / \mathrm{CN}(\mathrm{M}=\mathrm{Pt}, \mathrm{Pd}, \mathrm{Rh}$ and $\mathrm{Ir})$ catalysts.

In addition, BET measurement was employed to explore surface areas and pore size distributions in $\mathrm{M} / \mathrm{CN}(\mathrm{M}=\mathrm{Pt}, \mathrm{Pd}, \mathrm{Rh}$ and $\mathrm{Ir}$ ) catalysts. As shown in Figure S2 and 
Table 1, the BET surface areas and pore sizes of the Pt/CN, Pd/CN, Rh/CN and Ir/CN catalysts are almost closed to each other. The values of BET surface area are distributed in $917.55-943.88 \mathrm{~m}^{2} / \mathrm{g}$, with the pore size distribution of 10.53-10.70 nm. It implies that the similar BET surface areas and pore sizes in four catalysts will have similar reactive species transfer.

The active species compositions and chemical states of the synthetic samples have been determined by XPS. As shown in Figure 3a, signals of $\mathrm{C} 1 \mathrm{~s}, \mathrm{O} 1 \mathrm{~s}$ and $\mathrm{N} 1 \mathrm{~s}$ are presented in the XPS spectra of $\mathrm{Pt} / \mathrm{CN}, \mathrm{Pd} / \mathrm{CN}, \mathrm{Rh} / \mathrm{CN}$ and $\mathrm{Ir} / \mathrm{CN}$ catalysts concurrently, which derive from the $\mathrm{CN}$ supports. The signals of $\mathrm{Pt} 4 f, \mathrm{Pd} 3 d, \mathrm{Rh} 3 d$ and $\mathrm{Ir} 4 f$ are also observed in their respective survey spectra. The high-resolution spectra of C 1s, N 1s, $\mathrm{Pt} 4 f, \mathrm{Pd} 3 d$, $\mathrm{Rh} 3 d$ and Ir $4 f$ were further studied and shown in Figure $3 \mathrm{~b}-\mathrm{d}$. As shown in Figure $3 \mathrm{~b}$, the $C$ species of four catalysts are almost the same, and the $C 1 \mathrm{~s}$ region is fitted into three peaks (C-C (284.60 eV), C-O $/ \mathrm{C}=\mathrm{N}(285.60 \mathrm{eV})$ and $\mathrm{C}=\mathrm{O} / \mathrm{C}-\mathrm{N}(287.95 \mathrm{eV}))$ [33]. A similar situation occurs on the $\mathrm{N} 1 \mathrm{~s}$ spectra of $\mathrm{M} / \mathrm{CN}(\mathrm{M}=\mathrm{Pt}, \mathrm{Pd}, \mathrm{Rh}$ and $\mathrm{Ir})$ catalysts. As shown in Figure 3c, the four fitting peaks located at 398.0, 399.48, 400.84 and $403.39 \mathrm{eV}$ belong to pyridinic $\mathrm{N}$, pyrrolic $\mathrm{N}$, graphitic $\mathrm{N}$, and oxidized $\mathrm{N}$, respectively [34]. The high-resolution spectra of active metals are present in Figure $3 \mathrm{~d}$. Pt $4 f_{7 / 2}$ and $\mathrm{Pt} 4 f_{5 / 2}$ peaks at 71.62 and $75.03 \mathrm{eV}$ are attributed to the $\mathrm{Pt}^{0}$ species, whereas $\mathrm{Pt} 4 f_{7 / 2}$ and $\mathrm{Pt} 4 f_{5 / 2}$ peaks at 73.52 and $76.23 \mathrm{eV}$ are attributed to the $\mathrm{Pt}^{2+}$ species [35]. The $\mathrm{Pd} 3 d_{7 / 2}$ and $\mathrm{Pd} 3 d_{5 / 2}$ of $\mathrm{Pd} / \mathrm{CN}$ catalyst at 335.46 and $340.63 \mathrm{eV}$ are attributed to the $\mathrm{Pd}^{0}$ species, while the peaks at 337.35 and $342.55 \mathrm{eV}$ are attributed to the $\mathrm{Pd}^{2+}$ species [36,37]. As the fitting spectra of the $\mathrm{Rh} 3 \mathrm{~d}$ region in Figure $3 d$, the copresence of metallic Rh state $\left(\mathrm{Rh} 3 d_{7 / 2}\right.$ at $307.27 \mathrm{eV}, \mathrm{Rh} 3 d_{5 / 2}$ at $311.90 \mathrm{eV}$ ) and oxidized Rh state ( $\mathrm{Rh} 3 d_{7 / 2}$ at $309.13 \mathrm{eV}, \mathrm{Rh} 3 d_{5 / 2}$ at $313.84 \mathrm{eV}$ ) on the surface of Rh/CN catalyst are exhibited [38]. Similarly, the fitting spectra of the Ir $4 \mathrm{f}$ region exhibit the copresence of metallic Ir state (Ir $4 f_{7 / 2}$ at $61.79 \mathrm{eV}$, Ir $4 f_{5 / 2}$ at $64.77 \mathrm{eV}$ ) and oxidized Ir state (Ir $4 f_{7 / 2}$ at $63.09 \mathrm{eV}, \operatorname{Ir} 4 f_{5 / 2}$ at $\left.66.07 \mathrm{eV}\right)$ on the surface of Ir/CN catalyst [39]. In summary, the differences in the electronic structure and chemical state of $\mathrm{M} / \mathrm{CN}(\mathrm{M}=\mathrm{Pt}$, $\mathrm{Pd}, \mathrm{Rh}$ and Ir) catalysts mainly come from the active metals.
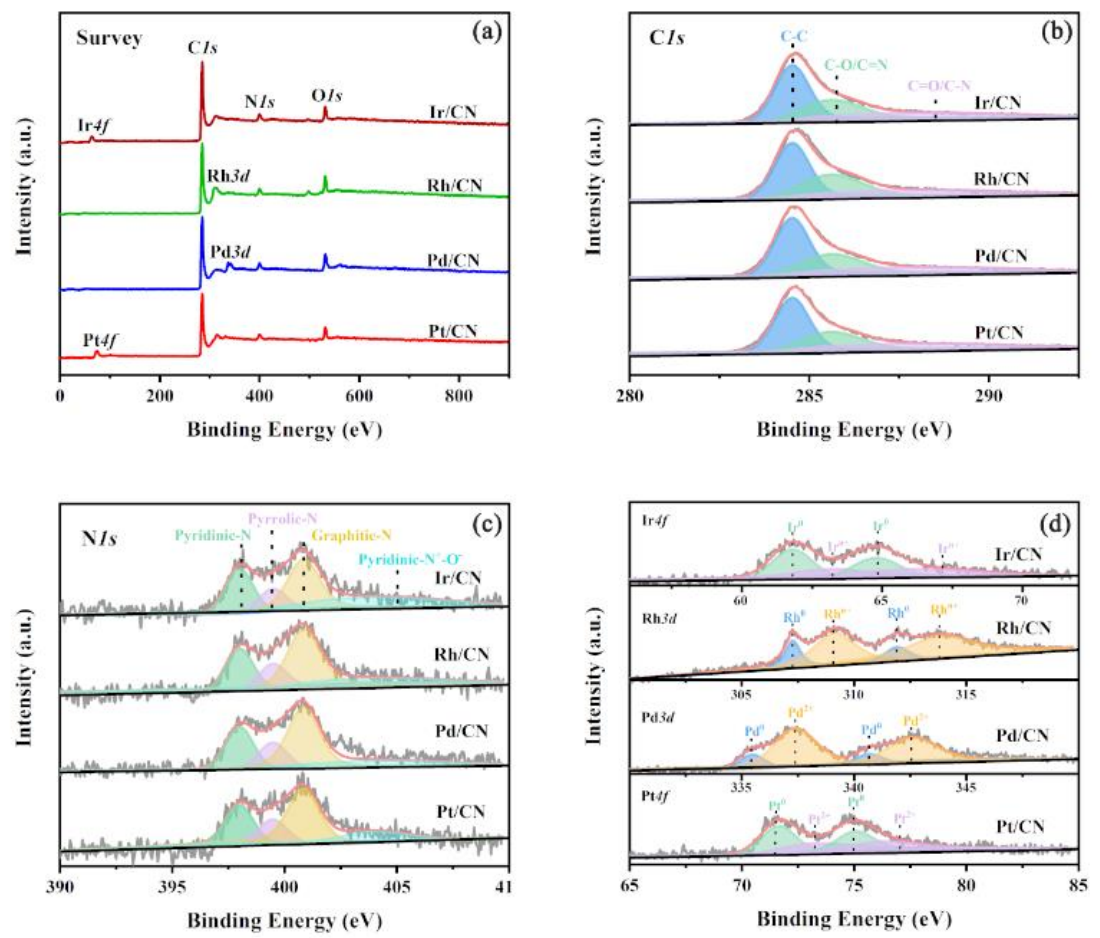

Figure 3. (a) XPS spectra, (b) C 1s spectra, (c) N 1s spectra and (d) Pt 4f, Pd 3d, Rh $3 d$ and Ir $4 f$ spectra of the $\mathrm{M} / \mathrm{CN}(\mathrm{M}=\mathrm{Pt}, \mathrm{Pd}$, Rh and Ir) catalysts. 
The catalytic activities of $\mathrm{M} / \mathrm{CN}(\mathrm{M}=\mathrm{Pt}, \mathrm{Pd}, \mathrm{Rh}$ and $\mathrm{Ir})$ catalysts were evaluated for cyclohexane dehydrogenation at various reaction temperatures of $180-210{ }^{\circ} \mathrm{C}$ for $90 \mathrm{~min}$. As shown in Figure 4, $\mathrm{Pt} / \mathrm{CN}$ exhibits the best hydrogen production efficiency. The amount of hydrogen produced at $180^{\circ} \mathrm{C}$ after 90 min with $\mathrm{Pt} / \mathrm{CN}, \mathrm{Pd} / \mathrm{CN}, \mathrm{Rh} / \mathrm{CN}$ and $\mathrm{Ir} / \mathrm{CN}$ catalysts are $7.30 \mathrm{mmol}, 4.02 \mathrm{mmol}, 1.91 \mathrm{mmol}, 0.40 \mathrm{mmol}$, respectively. The hydrogen production efficiencies of all synthetic catalysts increased with the reaction temperature from 180 to $210^{\circ} \mathrm{C}$. As shown in Figure 5, the cyclohexane conversions of $\mathrm{Pt} / \mathrm{CN}, \mathrm{Pd} / \mathrm{CN}$, $\mathrm{Rh} / \mathrm{CN}$ and $\mathrm{Ir} / \mathrm{CN}$ catalysts at $180{ }^{\circ} \mathrm{C}$ are $62.83 \%, 34.58 \%, 16.09 \%$ and $3.37 \%$, while the corresponding cyclohexane conversions at $210{ }^{\circ} \mathrm{C}$ are $96.22 \%, 77.16 \%, 32.85 \%$ and $10.15 \%$, respectively. Moreover, the liquid and gas products of all synthetic catalysts were analyzed by GC. The results presented in Figure 5 indicate that only cyclohexane, benzene and $\mathrm{H}_{2}$ are detected, implying the highly selectivity of $\mathrm{M} / \mathrm{CN}$ in cyclohexane dehydrogenation.
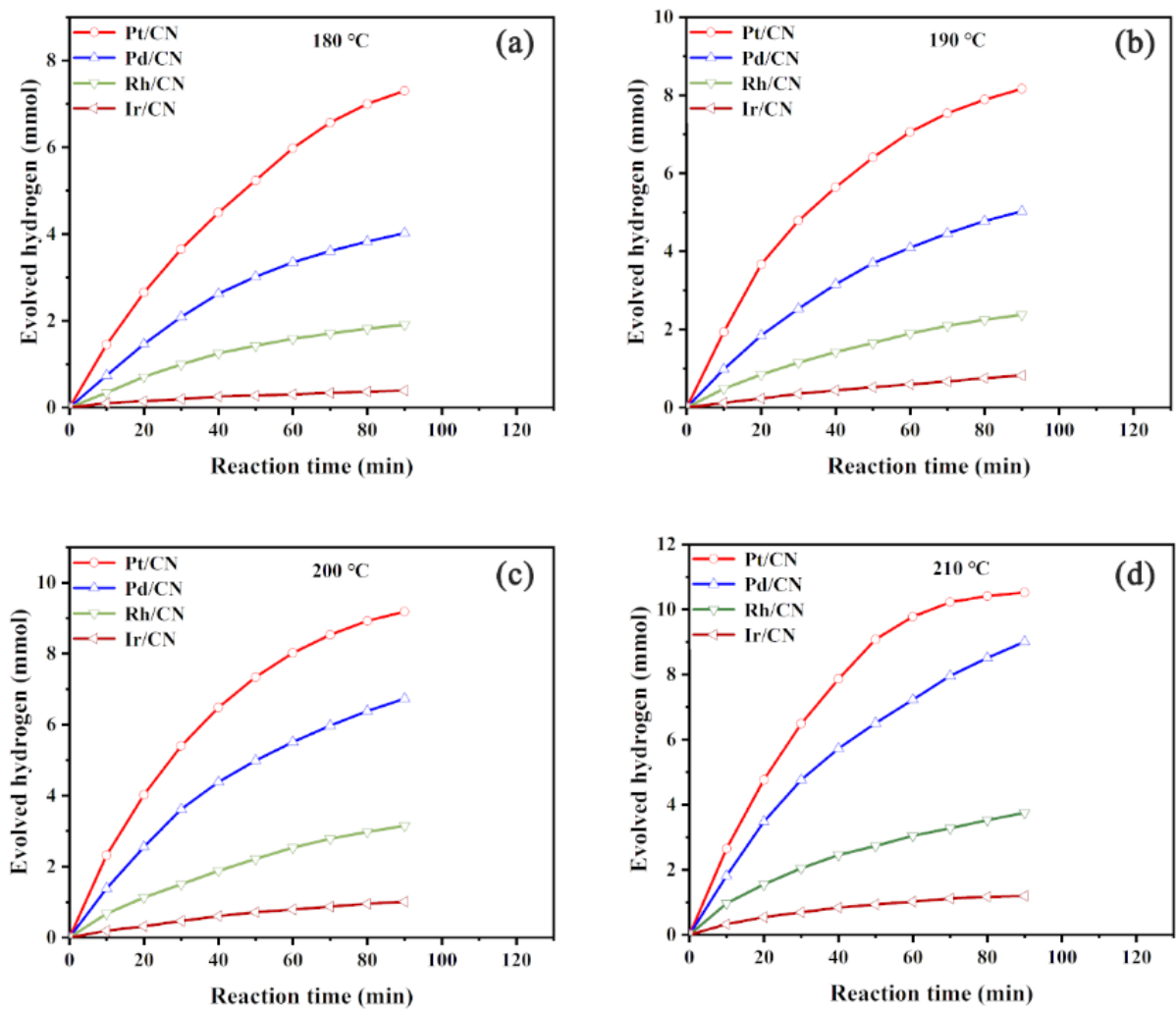

Figure 4. Hydrogen production curves of cyclohexane dehydrogenation with $\mathrm{M} / \mathrm{CN}(\mathrm{M}=\mathrm{Pt}, \mathrm{Pd}, \mathrm{Rh}$ and Ir) catalysts at (a) $180{ }^{\circ} \mathrm{C}$, (b) $190^{\circ} \mathrm{C}$, (c) $200^{\circ} \mathrm{C}$ and (d) $210^{\circ} \mathrm{C}$.

To further clarify the catalytic activities of active metals, the turnover frequencies (TOF) based on surface atoms of active metals of all synthetic catalysts for cyclohexane dehydrogenation were calculated according to the following two equations [40]:

$$
\operatorname{TOF}\left(h^{-1} \text {, surface }\right)=\frac{\frac{1}{3} \times \text { rate of } \mathrm{H}_{2}\left(\text { mol } \bullet h^{-1}\right)}{D \times \text { moles of active metal }(\mathrm{mol})}
$$

where the rate of $\mathrm{H}_{2}$ is the rate at hydrogen production of $0.05 \mathrm{mmol}, D$ is the dispersion of active metal.

The dispersion of active metal $(D)$ was calculated by equation:

$$
D(\%)=\frac{6 \times C \times M \times 10^{9}}{\rho \times d \times N_{A}} \times 100
$$


where $C$ is the number of active metal surface atoms (Pt: $1.24 \times 10^{19}$ atoms $/ \mathrm{m}^{2}$, Pd: $1.27 \times 10^{19}$ atoms $/ \mathrm{m}^{2}$, Rh: $1.33 \times 10^{19}$ atoms $/ \mathrm{m}^{2}$, Ir: $1.30 \times 10^{19}$ atoms $\left./ \mathrm{m}^{2}\right), M$ is the molar weight of active metal (Pt:195.08 g/mol, Pd: 106.42 g/mol, Rh: $102.90 \mathrm{~g} / \mathrm{mol}$, Ir: $192.20 \mathrm{~g} / \mathrm{mol}), \rho$ is the density of active metal $\left(\mathrm{Pt}: 2.145 \times 10^{7} \mathrm{~g} / \mathrm{m}^{3}, \mathrm{Pd}: 1.202 \times 10^{7} \mathrm{~g} / \mathrm{m}^{3}\right.$, Rh: $1.241 \times 10^{7} \mathrm{~g} / \mathrm{m}^{3}$, Ir: $\left.2.256 \times 10^{7} \mathrm{~g} / \mathrm{m}^{3}\right), d$ is the average particle size of active metal, $N_{A}$ is the Avogadro constant $\left(6.02 \times 10^{23} \mathrm{~mol}^{-1}\right)$.
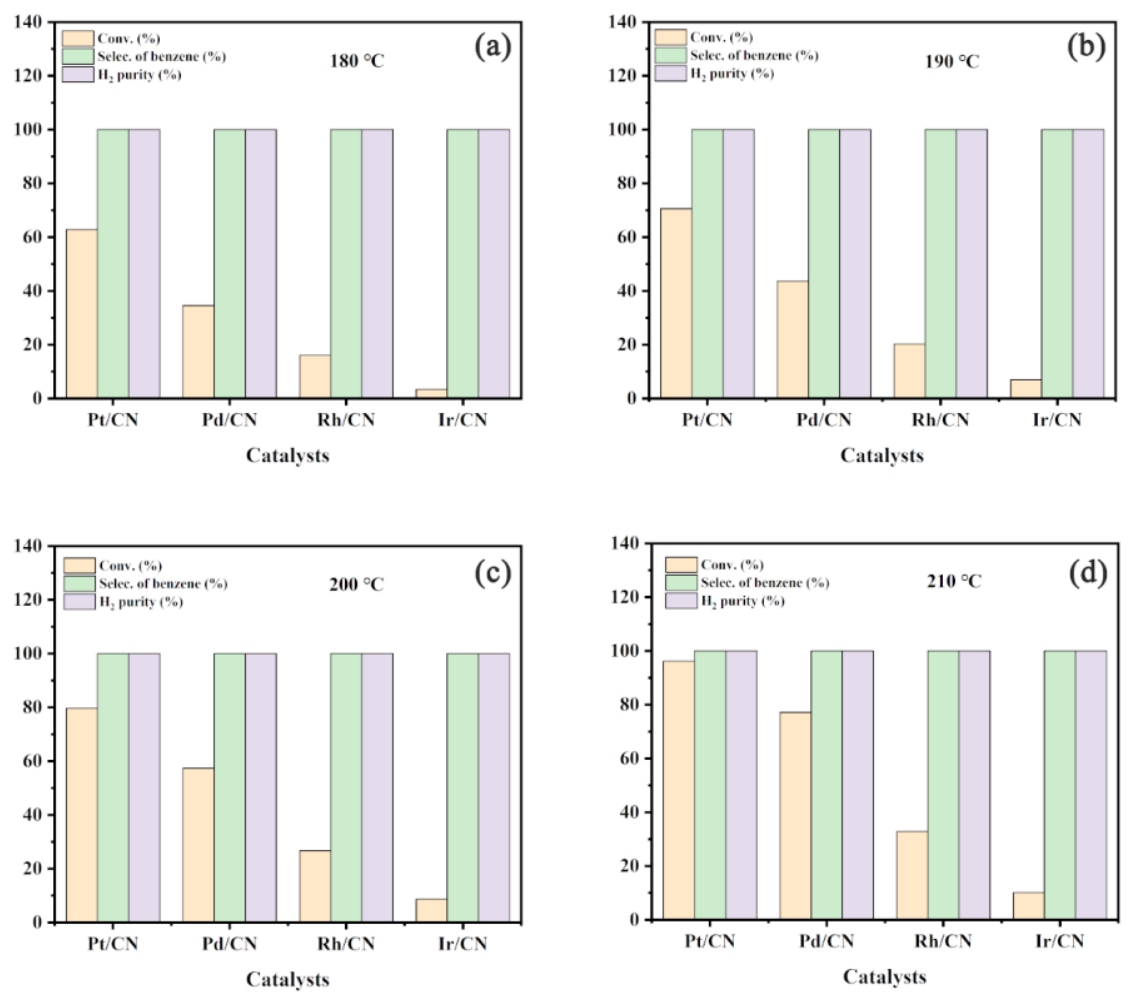

Figure 5. Cyclohexane conversions, selectivities of benzene and $\mathrm{H}_{2}$ purities with $\mathrm{M} / \mathrm{CN}(\mathrm{M}=\mathrm{Pt}, \mathrm{Pd}$, Rh and Ir) catalysts at (a) $180{ }^{\circ} \mathrm{C},\left(\right.$ b) $190{ }^{\circ} \mathrm{C}$, (c) $200{ }^{\circ} \mathrm{C}$ and (d) $210^{\circ} \mathrm{C}$.

As displayed in Figure 6a, $\mathrm{Pt} / \mathrm{CN}$ exhibits the highest TOF values in the whole temperature range of $180-210{ }^{\circ} \mathrm{C}$, followed by $\mathrm{Pd} / \mathrm{CN}, \mathrm{Rh} / \mathrm{CN}$ and $\mathrm{Ir} / \mathrm{CN}$ catalysts successively. Typically, the TOF value of $\mathrm{Pt} / \mathrm{CN}, \mathrm{Pd} / \mathrm{CN}, \mathrm{Rh} / \mathrm{CN}$ and $\mathrm{Ir} / \mathrm{CN}$ catalysts at the reaction temperature of $180^{\circ} \mathrm{C}$ is $269.32,108.78,44.15,31.73 \mathrm{~h}^{-1}$, respectively, with the corresponding TOF value at $210{ }^{\circ} \mathrm{C}$ of $492.52,268.09,127.39,102.20 \mathrm{~h}^{-1}$, respectively. It indicates that the activity order of the $\mathrm{M} / \mathrm{CN}$ catalysts on cyclohexane dehydrogenation is $\mathrm{Pt} / \mathrm{CN}>$ $\mathrm{Pd} / \mathrm{CN}>\mathrm{Rh} / \mathrm{CN}>\mathrm{Ir} / \mathrm{CN}$. In addition, compared with other reported catalysts, $\mathrm{Pt} / \mathrm{CN}$ and $\mathrm{Pd} / \mathrm{CN}$ exhibit excellent hydrogen production performance (Table S3). Moreover, the difference of catalytic activity of catalysts is closely related to reaction temperature. The TOF value of Pt/CN catalyst was calculated to be 8.49 times that of $\mathrm{Ir} / \mathrm{CN}$ catalyst at $180^{\circ} \mathrm{C}$, corresponding to be 4.82 times at $210^{\circ} \mathrm{C}$. It demonstrates that the difference of catalytic activity between different active metals diminishes with the increase in temperature. 

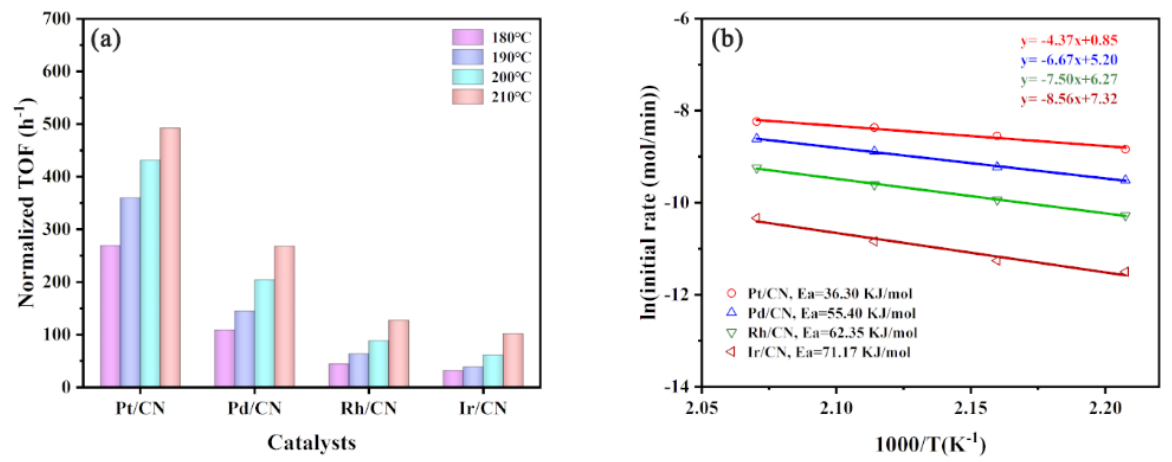

Figure 6. (a) TOF values at $180-210{ }^{\circ} \mathrm{C}$ and (b) Arrhenius plots of cyclohexane dehydrogenation.

To investigate the thermodynamic effects of cyclohexane dehydrogenation with $\mathrm{M} / \mathrm{CN}$ catalysts, activation energies (Ea) were estimated by the Arrhenius equation [41,42]. As shown in Figure $6 \mathrm{~b}$, the Ea values were calculated and listed as follows: $\mathrm{Pt} / \mathrm{CN}$ $\left(36.30 \mathrm{~kJ} \mathrm{~mol}^{-1}\right)<\mathrm{Pd} / \mathrm{CN}-2.3\left(55.40 \mathrm{~kJ} \mathrm{~mol}^{-1}\right)<\mathrm{Rh} / \mathrm{CN}\left(62.35 \mathrm{~kJ} \mathrm{~mol}^{-1}\right)<\mathrm{Ir} / \mathrm{CN}$ $\left(71.17 \mathrm{~kJ} \mathrm{~mol}^{-1}\right)$. The results are consistent with the trend of TOF values of the M/CN catalysts on cyclohexane dehydrogenation.

\subsection{Effect of Molecular Structure}

In catalytic cycloalkane dehydrogenation, both active metals and the structure of the reactant will affect the catalytic performance. In this work, seven cycloalkanes with different alkyl substituent were selected to explore the influences of structure on cycloalkane dehydrogenation, which was carried out with $\mathrm{Pt} / \mathrm{CN}$ as catalyst. The structure and hydrogen storage density of the chosen cycloalkanes are shown in Figure 7.<smiles>C1CCCCC1</smiles>

Cyclohexane $(7.2 \mathrm{wt} \%)$<smiles>CC1CCC(C)C(C)C1</smiles>

$1,2,4$-Trimethylcyclohexane $(4.7 \mathrm{wt} \%)$<smiles>CC1CCCCC1</smiles>

Methylcyclohexane $(6.2 \mathrm{wt} \%)$<smiles>CC1CCCC(C)C1C</smiles>

$1,2,3-$ Trimethylcyclohexane $(4.7 \mathrm{wt} \%)$<smiles>CCC1CCCCC1</smiles>

thylcyclohexane $(5.3 \mathrm{wt} \%)$<smiles>CC1CCC(C)CC1</smiles>

1,4-Dimethylcyclohexane $(5.3 \mathrm{wt} \%)$<smiles>CC1CC(C)CC(C)C1</smiles>

$1,3,5$-Trimethylcyclohexane $(4.7 \mathrm{wt} \%)$

Figure 7. The molecular structure and hydrogen storage density of the chosen cycloalkanes.

Firstly, cyclohexane $(\mathrm{CH})$, methylcyclohexane $(\mathrm{MCH})$ and ethylcyclohexane $(\mathrm{ECH})$ were employed to investigate the effect of the substituent group on cycloalkane dehydrogenation. As shown in Figure S3, the hydrogen production of $\mathrm{CH}$ dehydrogenation is the better than that of $\mathrm{MCH}$ and $\mathrm{ECH}$ at a whole temperature range of $180-210{ }^{\circ} \mathrm{C}$ after $90 \mathrm{~min}$. However, the $\mathrm{CH}$ conversion is worse than that of $\mathrm{MCH}$ and $\mathrm{ECH}$ (Figure S4). The mismatch between hydrogen production and reactant conversion is due to the difference in hydrogen storage density of reactants. In order to eliminate the effect of hydrogen density of reactants, the relative rate of hydrogen production $(r)$ was applied instead of TOF to 
compare the dehydrogenation performances of different cycloalkanes. The $r$ value was calculated by the Equation (3).

$$
r\left(\text { min }^{-1}\right)=\frac{\text { rate of } \mathrm{H}_{2}\left(\text { mol } \bullet \text { min }^{-1}\right)}{\text { moles of cycloalkanes }(\mathrm{mol})}
$$

where the rate of $\mathrm{H}_{2}$ is the rate at hydrogen production of $0.05 \mathrm{mmol}$. Figure $8 \mathrm{a}$. The $\mathrm{r}$ value of $\mathrm{MCH}$ dehydrogenation is the biggest in the whole temperature range of $180-210{ }^{\circ} \mathrm{C}$, followed by ECH and $\mathrm{CH}$ successively. It indicated that the dehydrogenation activities of the three cycloalkanes follow the order of $\mathrm{MCH}>\mathrm{ECH}>\mathrm{CH}$. Significantly, the difference of dehydrogenation activity between different reactants decreases with the increase in temperature. Therefore, Ea of the three-cycloalkane dehydrogenation were estimated and shown in Figure 8b. The Ea values are listed as follows: $\mathrm{MCH}\left(33.33 \mathrm{~kJ} \mathrm{~mol}^{-1}\right)<\mathrm{ECH}$ $\left(35.16 \mathrm{~kJ} \mathrm{~mol}^{-1}\right)<\mathrm{CH}\left(36.30 \mathrm{~kJ} \mathrm{~mol}^{-1}\right)$, which are consistent with the trend of $\mathrm{r}$ values of the three-cycloalkane dehydrogenation. The results reveal that the addition of a methyl or ethyl group can improve the dehydrogenation activity of cycloalkanes, and the methyl group is more conducive to cycloalkane dehydrogenation than the ethyl group.
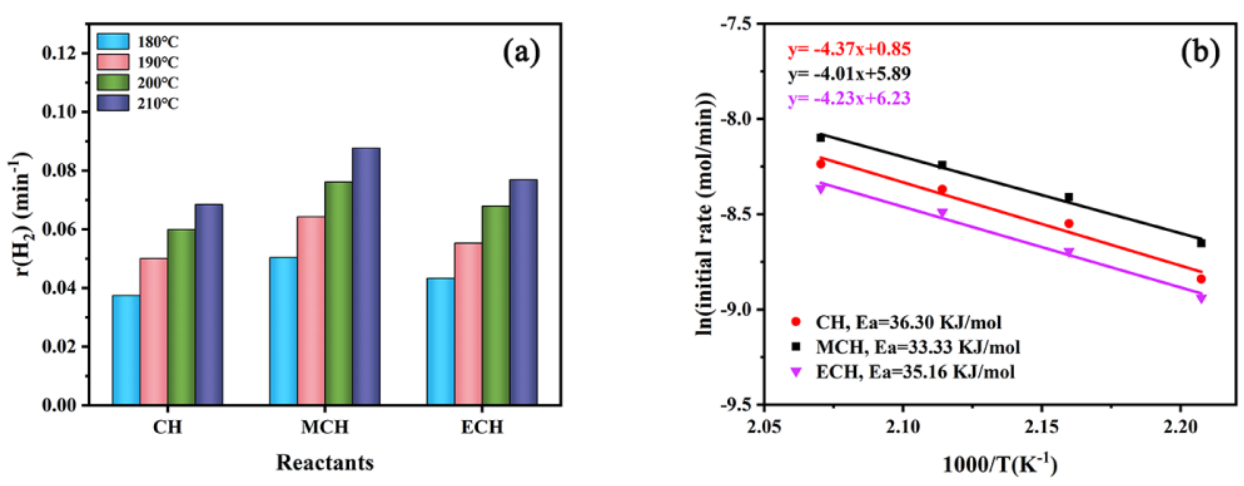

Figure 8. (a) $\mathrm{r}$ vales at $180-210{ }^{\circ} \mathrm{C}$; (b) Arrhenius plots for $\mathrm{CH}, \mathrm{MCH}$ and $\mathrm{ECH}$ dehydrogenation with $\mathrm{Pt} / \mathrm{CN}$ catalyst.

Subsequently, the effect of quantity of methyl substituent on cycloalkane dehydrogenation was investigated with cyclohexane $(\mathrm{CH})$, methylcyclohexane $(\mathrm{MCH}), 1,4-$ dimethylcyclohexane (1,4-DMCH) and 1,2,4-trimethylcyclohexane (1,2,4-TMCH) as model compounds. The dehydrogenation performances of selected cycloalkanes are displayed in Figures S5 and S6. A situation similar to that discussed above has emerged. The results of hydrogen production and reactant conversion are inconsistent. By comparing the $\mathrm{r}$ values as shown in Figure 9a, the dehydrogenation activity is in the following order: 1,2,4-TMCH $>1,4-\mathrm{DMCH}>\mathrm{MCH}>\mathrm{CH}$. Moreover, the same trend is observed in Ea of cycloalkane dehydrogenation shown in Figure 9b. The experimental results demonstrate that the increase in methyl substituent makes cycloalkanes release hydrogen more easily.
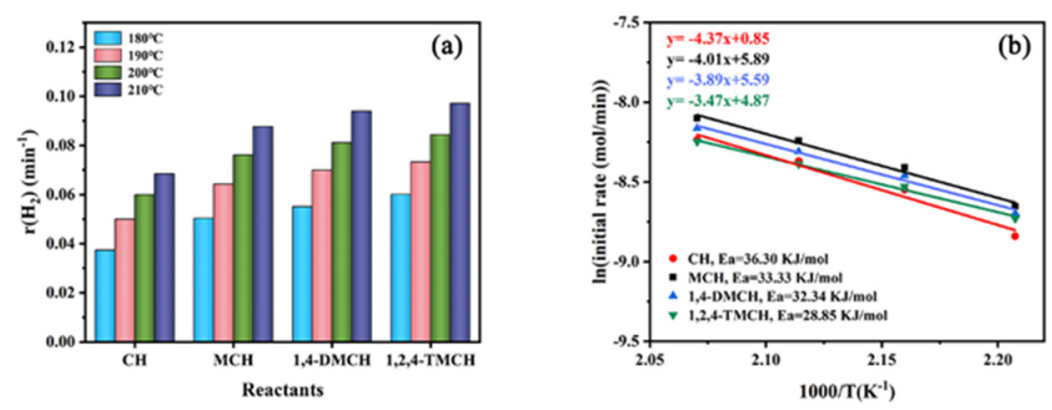

Figure 9. (a) $\mathrm{r}$ vales at $180-210^{\circ} \mathrm{C}$; (b) Arrhenius plots for $\mathrm{CH}, \mathrm{MCH}, 1,4-\mathrm{TMCH}$ and 1,2,4-TMCH dehydrogenation with $\mathrm{Pt} / \mathrm{CN}$ catalyst. 
Finally, 1,2,3-trimethylcyclohexane (1,2,3-TMCH), 1,2,4-trimethylcyclohexane (1,2,4$\mathrm{TMCH})$ and 1,3,5-trimethylcyclohexane $(1,3,5-\mathrm{TMCH})$ were selected to explore the effect of the substitution position. Because the hydrogen storage density of the three reactants is the same, the trend of hydrogen production efficiency (Figure S7) and reactant conversion (Figure S8) and $r$ value (Figure 10a) of the three cycloalkanes are consistent. As shown in Figure 10a, the $r$ values are listed as follows at the whole temperature range: 1,3,5-TMCH > $1,2,3-\mathrm{TMCH}>1,2,4-\mathrm{TMCH}$. With the increase in reaction temperature, the $\mathrm{r}$ values of the three cycloalkanes gradually approached. Furthermore, the Ea of the three-cycloalkane dehydrogenation exhibits the same trend (Figure 10b). The results demonstrate that the positions of methyl substituents affect the dehydrogenation performance.
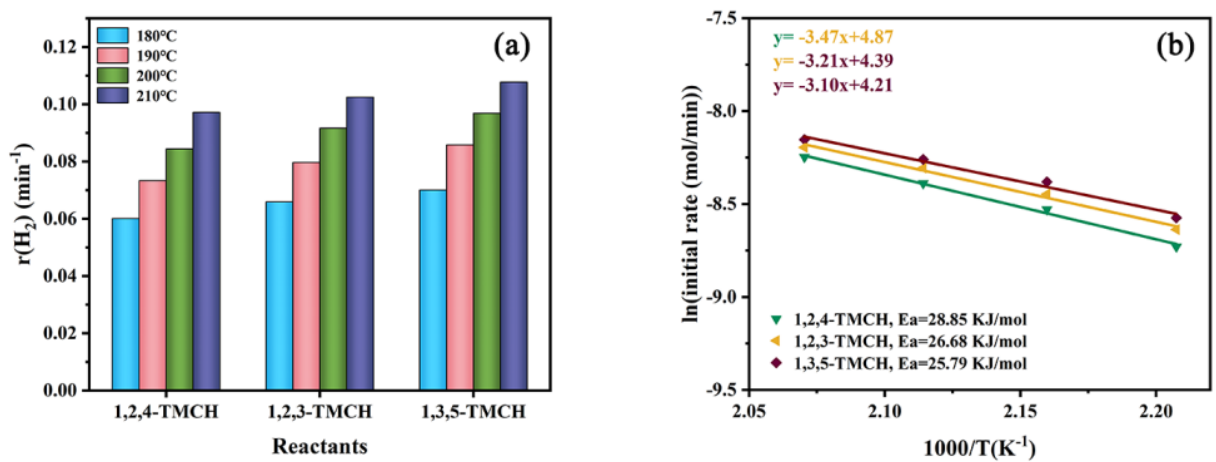

Figure 10. (a) $\mathrm{r}$ vales at $180-210^{\circ} \mathrm{C}$; (b) Arrhenius plots for 1,2,4-TMCH, 1,2,3-TMCH and 1,3,5-TMCH dehydrogenation with $\mathrm{Pt} / \mathrm{CN}$ catalyst.

\section{Conclusions}

In summary, we investigated the catalytic role of metal ( $\mathrm{Pt}, \mathrm{Pd}$, $\mathrm{Rh}$ and $\mathrm{Ir}$ ) nanoparticles supported on nitrogen-doped carbon using cyclohexane dehydrogenation as the model reaction. $\mathrm{Pt} / \mathrm{CN}$ shows the best catalytic activity for cyclohexane dehydrogenation, and the dehydrogenation activity of the four metals is as follows: $\mathrm{Pt}>\mathrm{Pd}>\mathrm{Rh}>\mathrm{Ir}$. Moreover, seven cycloalkanes were selected to explore the role of molecular structure on cycloalkanes dehydrogenation. The results show that (1) adding alkyl substituents can improve the dehydrogenation activity of cycloalkanes, methyl is more conducive to cycloalkane dehydrogenation than ethyl; (2) the increased quantity of methyl substituent makes cycloalkanes release hydrogen more easily; (3) the dehydrogenation activity of cyclohexane is affected by the position of substituents. This study is helpful to understand the role of active metal and molecular structure on catalytic dehydrogenation of cycloalkanes and provides strategies for highly efficient catalytic cycloalkane dehydrogenation.

Supplementary Materials: The following are available online at https:/ /www.mdpi.com/article/10 $.3390 /$ nano11112846/s1, Table S1: Dehydrogenation performance of cyclohexane over the synthetic catalysts at $180{ }^{\circ} \mathrm{C}$; Table S2. The element analysis data of CN; Figure S1: Size distributions of metal nanoparticles on (a) Pt/CN, (b) Pd/CN, (c) Rh/CN and (d) Ir/CN; Figure S2: (a) $\mathrm{N}_{2}$ adsorptiondesorption isotherms and (b) pore size distribution curves of the $\mathrm{CN}$ support and $\mathrm{M} / \mathrm{CN}(\mathrm{M}=\mathrm{Pt}, \mathrm{Pd}$, Rh and Ir) catalysts; Table S3. Comparison of dehydrogenation performance of cycloalkanes reported in literature; Figure S3: hydrogen production curves of $\mathrm{CH}, \mathrm{MCH}$ and $\mathrm{ECH}$ dehydrogenation at (a) $180{ }^{\circ} \mathrm{C}$, (b) $190{ }^{\circ} \mathrm{C}$, (c) $200{ }^{\circ} \mathrm{C}$ and $210^{\circ} \mathrm{C}$; Figure S4: cycloalkane conversions, selectivities and $\mathrm{H}_{2}$ purities of $\mathrm{CH}, \mathrm{MCH}$ and $\mathrm{ECH}$ dehydrogenation at (a) $180{ }^{\circ} \mathrm{C}$, (b) $190^{\circ} \mathrm{C}$, (c) $200^{\circ} \mathrm{C}$ and (d) $210^{\circ} \mathrm{C}$; Figure S5: hydrogen production curves of $\mathrm{CH}, \mathrm{MCH}, 1,4-\mathrm{DMCH}$ and 1,2,4-TMCH at the temperatures of (a) $180{ }^{\circ} \mathrm{C}$, (b) $190^{\circ} \mathrm{C}$, (c) $200{ }^{\circ} \mathrm{C}$ and $210{ }^{\circ} \mathrm{C}$; Figure S6. Cycloalkane conversions, selectivities and $\mathrm{H}_{2}$ purities of $\mathrm{CH}, \mathrm{MCH}, 1,4-\mathrm{DMCH}$ and 1,2,4-TMCH dehydrogenation at (a) $180{ }^{\circ} \mathrm{C}$, (b) $190{ }^{\circ} \mathrm{C}$, (c) $200{ }^{\circ} \mathrm{C}$ and (d) $210{ }^{\circ} \mathrm{C}$; Figure S7: hydrogen production curves of 1,2,4-TMCH, 1,2,3-TMCH and 1,3,5-TMCH dehydrogenation at the temperatures of (a) $180^{\circ} \mathrm{C}$, (b) $190{ }^{\circ} \mathrm{C}$, (c) $200{ }^{\circ} \mathrm{C}$ and $210{ }^{\circ} \mathrm{C}$; Figure S8: cycloalkane conversions, selectivities and $\mathrm{H}_{2}$ purities of 1,2,4-TMCH, 1,2,3-TMCH and 1,3,5-TMCH dehydrogenation at (a) $180{ }^{\circ} \mathrm{C}$, (b) $190{ }^{\circ} \mathrm{C}$, (c) $200{ }^{\circ} \mathrm{C}$ and (d) $210{ }^{\circ} \mathrm{C}$. 
Author Contributions: Conceptualization, J.W. and H.L.; methodology, J.W. and Z.W.; validation, S.F. and G.X.; formal analysis, J.W.; investigation, J.W. and S.W.; writing-original draft preparation, J.W.; writing-review and editing, J.W., A.G., H.L. and Z.W.; visualization, H.L. and Z.W.; supervision, H.L. and Z.W. All authors have read and agreed to the published version of the manuscript.

Funding: This work was supported by the National Natural Science Foundation of China (Grant 21908248), the Fundamental Research Funds for the Central Universities (Grant 19CX02013A), and the China National Petroleum Corporation (PRIKY19022).

Data Availability Statement: The data presented in this study are available on request from the corresponding author.

Conflicts of Interest: The authors declare no conflict of interest.

\section{References}

1. Schlapbach, L.; Züttel, A. Hydrogen-storage materials for mobile applications. Nature 2001, 414, 353-358. [CrossRef]

2. Patni, A.N.; Mantri, A.S.; Debashis, K. Ionic liquid promoted dehydrogenation of amine boranes: A review. Int. J. Hydrogen Energy 2021, 46, 11761-11781. [CrossRef]

3. Abdelhamid, H.N. A review on hydrogen generation from the hydrolysis of sodium borohydride. Int. J. Hydrogen Energy 2021, 46, 726-765. [CrossRef]

4. Nakayama, J.; Kasai, N.; Shibutani, T.; Miyake, A. Security risk analysis of a hydrogen fueling station with an on-site hydrogen production system involving methylcyclohexane. Int. J. Hydrogen Energy 2019, 44, 9110-9119. [CrossRef]

5. Zhu, Q.; Xu, Q. Liquid organic and inorganic chemical hydrides for high-capacity hydrogen storage. Energy Environ. Sci. 2015, 8, 478-512. [CrossRef]

6. Zhu, T.; Yang, M.; Chen, X.; Dong, Y.; Zhang, Z.; Cheng, H. A highly active bifunctional Ru-Pd catalyst for hydrogenation and dehydrogenation of liquid organic hydrogen carriers. J. Catal. 2019, 378, 382-391. [CrossRef]

7. Chen, H.; Shuang, H.; Lin, W.; Li, X.; Zhang, Z.; Li, J.; Fu, J. Tuning interfacial electronic properties of palladium oxide on vacancy-abundant carbon nitride for low-temperature dehydrogenation. ACS Catal. 2021, 11, 6193-6199. [CrossRef]

8. Li, X.; Shen, P.; Han, X.; Wang, Y.; Zhu, Y.; Wu, Z. Dehydrogenation mechanisms of liquid organic hydrogen carriers over Pt, Pd, Rh, and Ni surfaces: Cyclohexane as a model compound. Appl. Surf. Sci. 2021, 543, 148769. [CrossRef]

9. Marella, R.K.; Madduluri, V.R.; Yu, T.; Venkateswarlu, K.; Kumar, J.S.; Sreenivasan, M.; Lakkaboyana, S.K. Highly active biomorphic $\mathrm{MgO} / \mathrm{C}$ supported $\mathrm{Cu}$ NPs direct catalytic coupling of 1,4-butanediol dehydrogenation and acetophenone hydrogenation using in-situ liberated $\mathrm{H}_{2}$. Mol. Catal. 2021, 507, 111561. [CrossRef]

10. Abdelhamid, H.N.; Goda, M.N.; Said, E. Selective dehydrogenation of isopropanol on carbonized metal-organic frameworks. Nano-Struct. Nano-Objects 2020, 24, 100605. [CrossRef]

11. Biniwale, R.; Rayalu, S.; Devotta, S.; Ichikawa, M. Chemical hydrides: A solution to high-capacity hydrogen storage and supply. Int. J. Hydrogen Energy 2008, 33, 360-365. [CrossRef]

12. Skubic, L.; Sovdat, J.; Teran, N.; Huš, M.; Kopač, D.; Likozar, B. Ab initio multiscale process modeling of ethane, propane and butane dehydrogenation reactions: A review. Catalysts 2020, 10, 1405. [CrossRef]

13. Gambo, Y.; Adamu, S.; Abdulrasheed, A.A.; Lucky, R.A.; Ba-Shammakh, M.S.; Hossain, M.M. Catalyst design and tuning for oxidative dehydrogenation of propane: A review. Appl. Catal. A-Gen. 2021,609, 117914. [CrossRef]

14. Rahman, S.T.; Choi, J.-R.; Lee, J.-H.; Park, S.-J. The role of $\mathrm{CO}_{2}$ as a mild oxidant in oxidation and dehydrogenation over catalysts: A review. Catalysts 2020, 10, 1075. [CrossRef]

15. Al-ShaikhAli, A.H.; Jedidi, A.; Anjum, D.H.; Cavallo, L.; Takanabe, K. Kinetics on NiZn bimetallic catalysts for hydrogen evolution via selective dehydrogenation of methylcyclohexane to toluene. ACS Catal. 2017, 7, 1592-1600. [CrossRef]

16. Xia, Z.; Liu, H.; Lu, H.; Zhang, Z.; Chen, Y. Study on catalytic properties and carbon deposition of Ni-Cu/SBA-15 for cyclohexane dehydrogenation. Appl. Surf. Sci. 2017, 422, 905-912. [CrossRef]

17. Hodoshima, S. Catalytic decalin dehydrogenation/naphthalene hydrogenation pair as a hydrogen source for fuel-cell vehicle. Int. J. Hydrogen Energy 2003, 28, 1255-1262. [CrossRef]

18. Sebastián, D.; Bordejé, E.G.; Calvillo, L.; Lázaro, M.J.; Moliner, R. Hydrogen storage by decalin dehydrogenation/naphthalene hydrogenation pair over platinum catalysts supported on activated carbon. Int. J. Hydrogen Energy 2008, 33, 1329-1334. [CrossRef]

19. Li, P.; Huang, Y.; Chen, D.; Zhu, J.; Zhao, T.; Zhou, X. CNFs-supported Pt catalyst for hydrogen evolution from decalin. Catal. Commun. 2009, 10, 815-818. [CrossRef]

20. Li, X.; Tuo, Y.; Jiang, H.; Duan, X.; Yu, X.; Li, P. Engineering Pt/carbon-nanofibers/carbon-paper composite towards highly efficient catalyst for hydrogen evolution from liquid organic hydride. Int. J. Hydrogen Energy 2015, 40, 12217-12226. [CrossRef]

21. Tuo, Y.; Shi, L.; Cheng, H.; Zhu, Y.; Yang, M.; Xu, J.; Han, Y.; Li, P.; Yuan, W. Insight into the support effect on the particle size effect of Pt/C catalysts in dehydrogenation. J. Catal. 2018, 360, 175-186. [CrossRef]

22. Kariya, N.; Fukuoka, A.; Utagawa, T.; Sakuramoto, M.; Goto, Y.; Ichikawa, M. Efficient hydrogen production using cyclohexane and decalin by pulse-spray mode reactor with Pt catalysts. Appl. Catal. A-Gen. 2003, 247, 247-259. [CrossRef] 
23. Hodoshima, S.; Arai, H.; Saito, Y. Liquid-film-type catalytic decalin dehydrogeno-aromatization for long-term storage and long-distance transportation of hydrogen. Int. J. Hydrogen Energy 2003, 28, 197-204. [CrossRef]

24. Wang, J.; Liu, H.; Fan, S.; Li, W.; Li, Z.; Yun, H.; Xu, X.; Guo, A.; Wang, Z. Size-dependent catalytic cyclohexane dehydrogenation with platinum nanoparticles on nitrogen-doped carbon. Energy Fuels 2020, 34, 16542-16551. [CrossRef]

25. Meng, J.; Zhou, F.; Ma, H.; Yuan, X.; Wang, Y.; Zhang, J. A review of catalysts for methylcyclohexane dehydrogenation. Top. Catal. 2021, 64, 509-520. [CrossRef]

26. Pande, J.V.; Shukla, A.; Biniwale, R.B. Catalytic dehydrogenation of cyclohexane over Ag-M/ACC catalysts for hydrogen supply. Int. J. Hydrogen Energy 2012, 37, 6756-6763. [CrossRef]

27. Xia, Z.; Liu, H.; Lu, H.; Zhang, Z.; Chen, Y. High Selectivity of Cyclohexane Dehydrogenation for $\mathrm{H}_{2}$ Evolution Over Cu/SBA-15 Catalyst. Catal. Lett. 2017, 147, 1295-1302. [CrossRef]

28. Pande, J.V.; Bindwal, A.B.; Pakade, Y.B.; Biniwale, R.B. Application of microwave synthesized Ag-Rh nanoparticles in cyclohexane dehydrogenation for enhanced $\mathrm{H}_{2}$ delivery. Int. J. Hydrogen Energy 2018, 43, 7411-7423. [CrossRef]

29. Lu, R.; Boethius, G.; Wen, S.; Su, Y.; Deng, W. Improved organic hydrogen carriers with superior thermodynamic properties Chem. Commun. 2009, 13, 1751-1753. [CrossRef]

30. Clot, E.; Eisenstein, O.; Crabtree, R.H. Computational structure-activity relationships in $\mathrm{H}_{2}$ storage: How placement of $\mathrm{N}$ atoms affects release temperatures in organic liquid storage materials. Chem. Commun. 2007, 2231-2233. [CrossRef] [PubMed]

31. Sotoodeh, F.; Smith, K.J. Structure sensitivity of dodecahydro-N-ethylcarbazole dehydrogenation over Pd catalysts. J. Catal. 2011, 279, 36-47. [CrossRef]

32. Fan, H.; Cheng, M.; Wang, L.; Song, Y.; Cui, Y.; Wang, R. Extraordinary electrocatalytic performance for formic acid oxidation by the synergistic effect of $\mathrm{Pt}$ and $\mathrm{Au}$ on carbon black. Nano Energy 2018, 48, 1-9. [CrossRef]

33. Wu, H.; Cheng, Y.; Wang, B.; Wang, Y.; Wu, M.; Li, W.; Liu, B.; Lu, S. Carbon dots-confined CoP-CoO nanoheterostructure with strong interfacial synergy triggered the robust hydrogen evolution from ammonia borane. J. Energy Chem. 2021, 57, 198-205. [CrossRef]

34. Zhang, F.; Ma, C.; Zhang, Y.; Li, H.; Fu, D.; Du, X.; Zhang, X.M. N-doped mesoporous carbon embedded Co nanoparticles for highly efficient and stable $\mathrm{H}_{2}$ generation from hydrolysis of ammonia borane. J. Power Sources 2018, 399, 89-97. [CrossRef]

35. Peng, R.; Li, S.; Sun, X.; Ren, Q.; Chen, L.; Fu, M.; Wu, J.; Ye, D. Size effect of Pt nanoparticles on the catalytic oxidation of toluene over Pt $/ \mathrm{CeO}_{2}$ catalysts. Appl. Catal. B Environ. 2018, 220, 462-470. [CrossRef]

36. Ruiz-García, C.; Heras, F.; Alonso-Morales, N.; Calvo, L.; Rodriguez, J.J.; Gilarranz, M.A. Enhancement of the activity of Pd/C catalysts in aqueous phase hydrodechlorination through doping of carbon supports. Catal. Sci. Technol. 2018, 8, 2598-2605. [CrossRef]

37. Soni, Y.; Pradhan, S.; Bamnia, M.K.; Yadav, A.K.; Jha, S.N.; Bhattacharyya, D.; Khan, T.S.; Haider, M.A.; Vinod, C.P. Spectroscopic evidences for the size dependent generation of Pd species responsible for the low temperature CO oxidation activity on Pd-SBA-15 nanocatalyst. Appl. Catal. B Environ. 2020, 272, 118934. [CrossRef]

38. Liu, X.; Han, Q.; Zhang, Y.; Wang, X.; Cai, S.; Wang, C.; Yang, R. Green and facile synthesis of Rh/GO nanocomposites for high catalytic performance. Appl. Surf. Sci. 2019, 471,929-934. [CrossRef]

39. Xue, Q.; Gao, W.; Zhu, J.; Peng, R.; Xu, Q.; Chen, P.; Chen, Y. Carbon nanobowls supported ultrafine iridium nanocrystals: An active and stable electrocatalyst for the oxygen evolution reaction in acidic media. J. Colloid Interf. Sci. 2018, 529, 325-331. [CrossRef]

40. Kim, Y.; Kim, D.H. Understanding the effect of Pd size on formic acid dehydrogenation via size-controlled Pd/C catalysts prepared by $\mathrm{NaBH}_{4}$ treatment. Appl. Catal. B Environ. 2019, 244, 684-693. [CrossRef]

41. Yang, X.; Li, Q.; Li, L.; Lin, J.; Yang, X.; Yu, C.; Liu, Z.; Fang, Y.; Huang, Y.; Tang, C. CuCo binary metal nanoparticles supported on boron nitride nanofibers as highly efficient catalysts for hydrogen generation from hydrolysis of ammonia borane. J. Power Sources 2019, 431, 135-143. [CrossRef]

42. Sun, W.; Wu, S.; Lu, Y.; Wang, Y.; Cao, Q.; Fang, W. Effective control of particle size and electron density of Pd/C and Sn-Pd/C nanocatalysts for vanillin production via base-free oxidation. ACS Catal. 2020, 10, 7699-7709. [CrossRef] 